\title{
Ultra-Fast Degradation of $p$-Aminophenol by a Nanostructured Iron Catalyst
}

\author{
Rocio Benavente $^{\dagger}$, David Lopez-Tejedor $^{+}{ }^{(1)}$, Carlos Perez-Rizquez ${ }^{+}$(i) and Jose M. Palomo * \\ Department of Biocatalysis, Institute of Catalysis (CSIC), Cantoblanco Campus UAM, Marie Curie 2, \\ 28049 Madrid, Spain; r.benavente@csic.es (R.B.); david.lopez@csic.es (D.L.-T.); c.p.rizquez@csic.es (C.P.-R.) \\ * Correspondence: josempalomo@icp.csic.es; Tel.: +34-91-585-4768; Fax: +34-91-585-4760 \\ + These authors contributed equally to this work.
}

Academic Editor: Xiao-Feng Wu

Received: 24 July 2018; Accepted: 24 August 2018; Published: 28 August 2018

\begin{abstract}
Full degradation of $p$-aminophenol in aqueous solution at room temperature by using a heterogeneous nanostructured iron hybrid catalyst in the presence of hydrogen peroxide is described. A nanostructured iron catalyst was prepared by in situ formation of iron carbonate nanorods on the protein network using an aqueous solution of an enzyme, lipase B from Candida antarctica (CAL-B). A second kind of iron nanostructured catalyst was obtained by the sunsequent treatment of the hybrid with an aqueous liquid extract of Mentha x piperita. Remarkable differences were observed using TEM imaging. When M. piperita extract was used, nanoparticles appeared instead of nanorods. Catalytic activity of these iron nanocatalysts was studied in the degradation of the environmental pollutant $p$-aminophenol (pAP) under different operating parameters, such as $\mathrm{pH}$, presence of buffer or hydrogen peroxide concentration. Optimal conditions were $\mathrm{pH} 4$ in acetate buffer $10 \mathrm{mM}$ containing $1 \%(v / v) \mathrm{H}_{2} \mathrm{O}_{2}$ for $\mathrm{FeCO}_{3} \mathrm{NRs} @ C A L B$, while for $\mathrm{FeCO}_{3}$ NRs@CALB-Mentha, water containing $1 \%$ $(v / v) \mathrm{H}_{2} \mathrm{O}_{2}$, resulted the best. A complete degradation of 100 ppm of pAP was achieved in 2 and $3 \mathrm{~min}$ respectively using $1 \mathrm{~g} \mathrm{Fe} / \mathrm{L}$. This novel nanocatalyst was recycled five times maintaining full catalytic performance.
\end{abstract}

Keywords: iron nanocatalyst; 4-aminophenol; environmental remediation; Mentha x piperita

\section{Introduction}

para-Aminophenol $(\mathrm{pAP})$ is an important compound with an broad range of industrial application as a raw material in the petroleum, rubber, dye, medicine and photographic industries. It is also a well-known hazardous environmental pollutant [1,2]. In particular, pAP is a direct intermediate in the synthesis of paracetamol, so pAP contamination of the environment is possible due to paracetamol degradation [3]. Skin, eyes and respiratory system irritation, and also detrimental effects in blood and kidneys are some of the described symptoms to pAP exposure [4]. Therefore, a pAP concentration of $50.0 \mathrm{ppm}$ has been established by the EU and the US as the maximum limit in paracetamol preparation [5]. Due to pAP toxicity, both to animals and the environment, pAP is a major environmental remediation issue.

Among the different approaches described for the degradation of this organic pollutant, the development and use of metal nanostructured materials has increased in recent years [6-8]. The high surface-to-volume ratio of nanomaterials compared to bulk materials, together with the advantages of being a heterogeneous phase, makes them attractive candidates for their application as catalysts [9-12]. In the other hand, iron is the most abundant metal in the planet, making it relatively inexpensive. In comparison with precious metals, iron is relatively nontoxic (i.e., it is considered by 
the regulatory authorities a "metal with minimum safety concern) [13]. Thus, iron (Fe) is extremely suitable for the elimination of environmental organic pollutants.

Several strategies have been described in the preparation of iron nanostructures. Depending on the metal source and experimental conditions, different iron species and nanostructures are obtained [14-18]. The most commonly obtained iron species nanoparticles are iron oxides like hematite $\left(\alpha-\mathrm{Fe}_{2} \mathrm{O}_{3}\right)$, maghemite $\left(\gamma-\mathrm{Fe}_{2} \mathrm{O}_{3}\right)$, magnetite $\left(\mathrm{Fe}_{3} \mathrm{O}_{4}\right)$, iron oxyhydroxide $(\mathrm{FeOOH})$ and in particular cases, $\alpha$-Fe in the form of nanoparticles, nanorods or even nanowires [19-22].

Here we present the preparation of a new type of iron nanostructured species: iron carbonate nanorods and nanoparticles. Well-dispersed iron nanostructures were synthesized in situ at room temperature in aqueous media by using an enzyme (Candida antarctica lipase B, CAL-B) as a biological matrix. The protein acted as stabilizing agent, also allowing the formation of a heterogeneous nanomaterial. A subsequent treatment of the formed nanohybrid with a liquid extract of Mentha $\mathrm{x}$ piperita was proposed as a variation of the original protocol. In the literature there are several examples of the use of plant extracts for the direct synthesis of nanoparticles [23,24]. However, to our knowledge, there are no precedents of protein-mediated coupled to the use of plant extracts in the synthesis of iron nanostructures. These methodologies represent a green alternative to conventional methods which involve the application of harsh conditions (e.g., high temperatures or the presence of organic solvents) and the necessity of highly controllable conditions or the utilization of special equipment $[25,26]$. Both iron nanohybrids were evaluated as catalysts in the degradation of $p$-aminophenol $(100 \mathrm{mg} / \mathrm{L})$ in aqueous media containing hydrogen peroxide. Different parameters of the degradation process were evaluated ( $\mathrm{pH}$, buffer presence, $\mathrm{H}_{2} \mathrm{O}_{2}$ concentration).

\section{Results and Discussion}

\subsection{Synthesis of Nanostructured Iron Carbonate Biohybrids}

The synthesis of the bionanohybrid catalyst was performed by the combination of an aqueous solution of lipase B from Candida antarctica with a fully aqueous soluble iron salt (Mohr's salt) at room temperature and under gentle stirring (Figure 1).
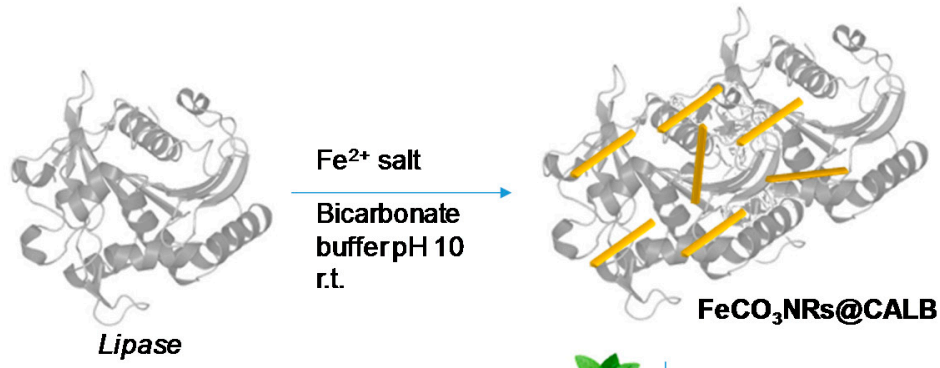

$\mathrm{FeCO}_{3}$ nanorod (NR)

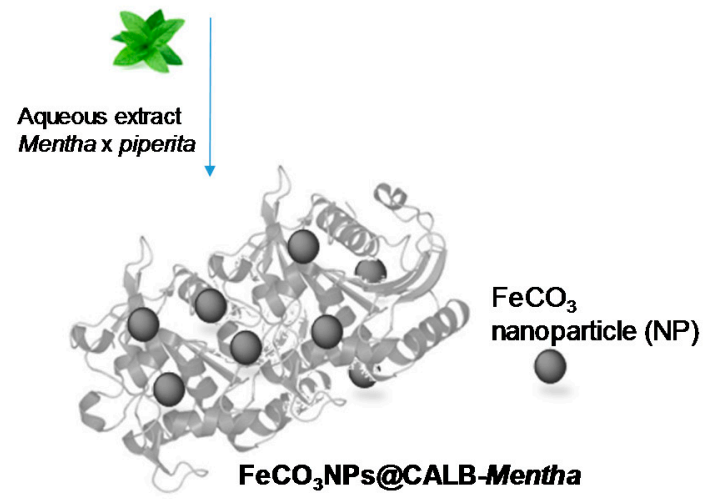

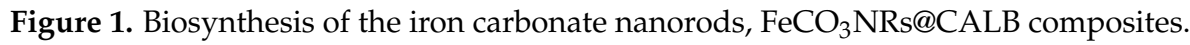


In order to control the $\mathrm{pH}$ of the final solution -which must be higher than the isoelectric point of the lipase $\mathrm{pI}=6$ to obtain a negatively charged protein and $\leq 10$ to avoid iron oxide nanoparticle formation in solution-, different buffers and different concentrations were tested, with $100 \mathrm{mM}$ of sodium bicarbonate ( $\mathrm{pH} 10)$ being identified as the best option. Then, commercial CAL-B solution (3.6 mL containing approx. $18 \mathrm{mg}$ protein calculated by Bradford assay [27]) were dissolved in $60 \mathrm{~mL}$ of $100 \mathrm{mM}$ of sodium bicarbonate $(\mathrm{pH} 10)$ and $600 \mathrm{mg}$ of $\left(\mathrm{NH}_{4}\right)_{2} \mathrm{Fe}\left(\mathrm{SO}_{4}\right)_{2}$ in solid form were added to the protein solution. At this iron salt concentration $(10 \mathrm{mg} / \mathrm{mL})$, the solution started to turn cloudy (first step in the bionanohybrid formation) after $30 \mathrm{~min}$ with a decrease in the $\mathrm{pH}$ of the solution to around 8 , which was conserved unaltered during all the incubation time. After 16-h of incubation, a solid was obtained, washed several times with distilled water, centrifuged and lyophilized overnight. ICP-OES analysis revealed that this new bionanohybrid contained $47 \mathrm{wt}$. \% of iron.

X-ray diffraction (XRD) analysis of the solid demonstrated the presence of iron (II) carbonate (siderite, $\mathrm{FeCO}_{3}$ ) as the main iron species, which is in concordance with previously described results $[28,29]$, although some minor contamination with iron oxide (magnetite or maghemite) was found (Figure 2a). X-ray photoelectron spectroscopy (XPS) analysis of the solid confirmed the iron species, specially the presence of Fe(III) in the sample (Figure $2 b, c)$.

a)

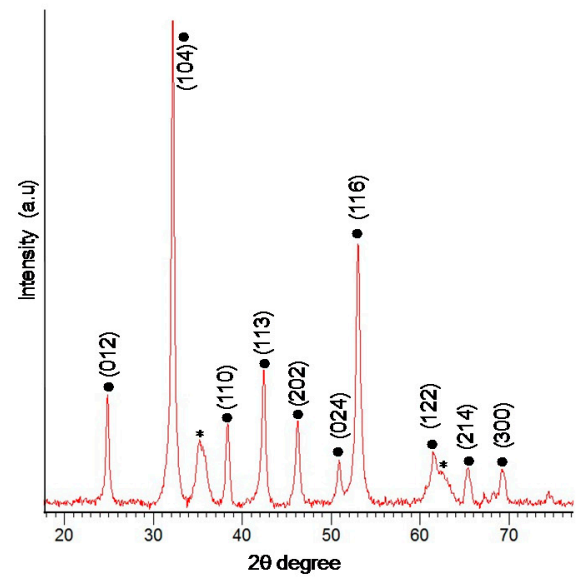

b)

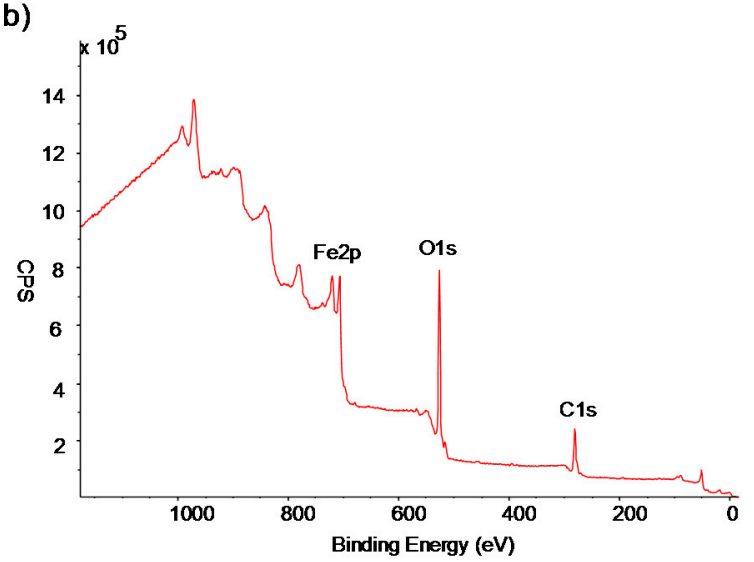

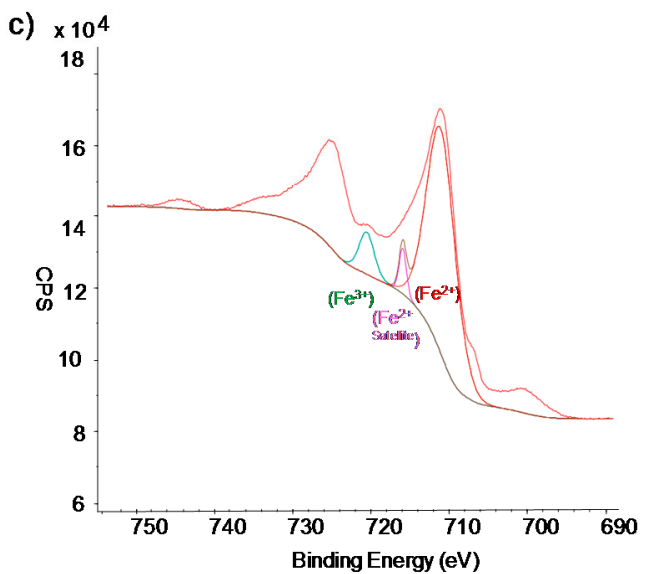

Figure 2. X-ray characterization of bionanohybrid. (a) XRD pattern $\left(\bullet \mathrm{FeCO}_{3},{ }^{*}\right.$ iron oxide impurity.). (b) XPS spectrum. (c) XPS Fe2p spectrum.

TEM analysis of the solid revealed the formation of unexpected nanorods (NRs) of iron carbonate with a size of approx. $7 \mathrm{~nm}$ diameter $\times 59 \mathrm{~nm}$ long induced by the protein matrix, obtaining the so-called $\mathrm{FeCO}_{3} \mathrm{NRs@CALB} \mathrm{bionanohybrid} \mathrm{(Figure} \mathrm{3).}$ 
a)

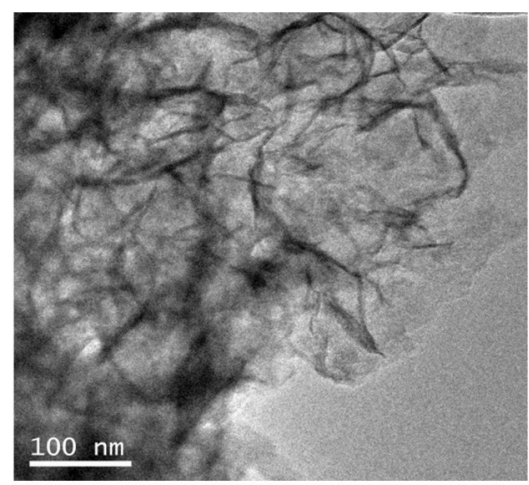

b)

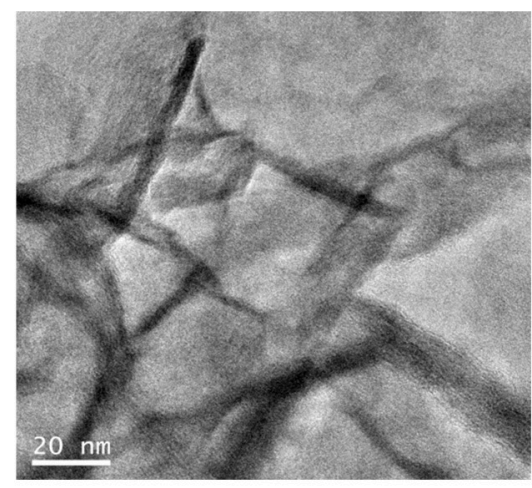

c)

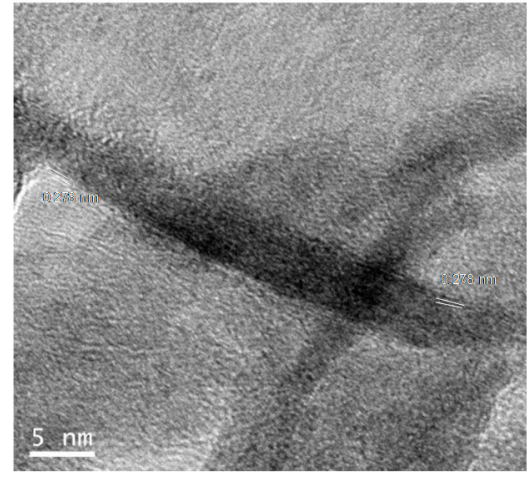

Figure 3. TEM analysis of $\mathrm{FeCO}_{3} \mathrm{NRs@CALB.} \mathrm{(a,b)} \mathrm{TEM.} \mathrm{(c)} \mathrm{HRTEM.}$

Considering the advantages of the use of plant extract in the stabilization or reduction of different metals [23,24], a second strategy was developed using an aqueous extract of Mentha x piperita.

The synthesis of the bionanohybrid was performed as previously described in this section. Thus, $3.6 \mathrm{~mL}$ of commercial CAL-B solution were dissolved in $60 \mathrm{~mL}$ of $100 \mathrm{mM}$ of sodium bicarbonate ( $\mathrm{pH} 10), 600 \mathrm{mg}$ of $\left(\mathrm{NH}_{4}\right)_{2} \mathrm{Fe}\left(\mathrm{SO}_{4}\right)_{2}$ were added and the mixture was incubated for $16 \mathrm{~h}$. After this time, the mixture was centrifuged and the supernatant removed. Then, the solid was added to $60 \mathrm{~mL}$ of an aqueous Mentha extract and the mixture was incubated for $30 \mathrm{~min}$. The solution rapidly turned black as well as the solid. Then, the solid was centrifuged, washed and lyophilized for $16 \mathrm{~h}$, affording a black solid.

This new solid, contained the same amount of $\mathrm{Fe}(47 \%$, measured by ICP) as the

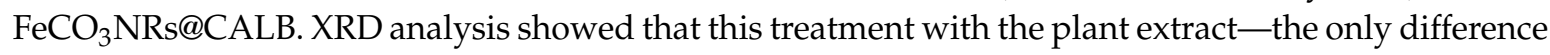
with the synthetic protocol of $\mathrm{FeCO}_{3} \mathrm{NRs} @ \mathrm{CALB}$-modified the iron species of the sample (Figure 4a). Although the main iron species in the solid were the same than in $\mathrm{FeCO}_{3} \mathrm{NRs@CALB}$, siderite, the amount of iron oxide increased (Figure 4a).

TEM analyses revealed the formation of nanoparticles of diameter size around 4-5 nm instead of nanorods (Figure $4 \mathrm{~b}-\mathrm{d}$ ). HRTEM showed regular lattice fringes with an interplanar spacing of $0.279 \mathrm{~nm}$ in nanoparticles (Figure $4 \mathrm{~d}$ ), which correspond to the (104) lattice planes of siderite [30]. The interplanar spacing in nanorods from $\mathrm{FeCO}_{3} \mathrm{NRs} @ \mathrm{CALB}$ was the same (Figure 3).

The treatment with Mentha extract, which in principle was used to act as reducing agent [23], seems to change the iron species reducing the size of the iron nanostructures formed from nanorods to nanoparticles. It has been described that for iron nanostructures the particular methodology is a critical step in order to obtain different morphologies $[14,15]$. 
a)

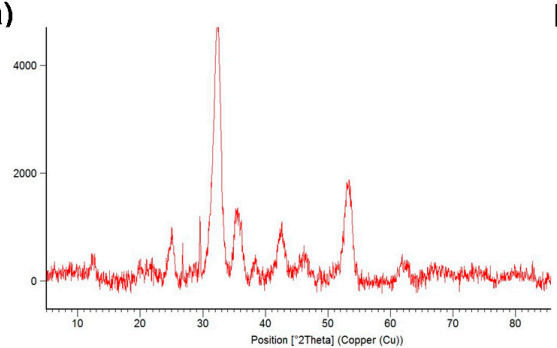

c)

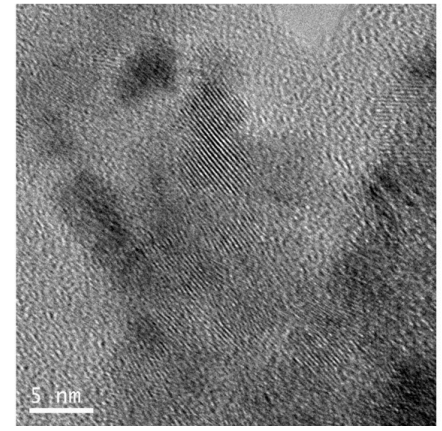

b)

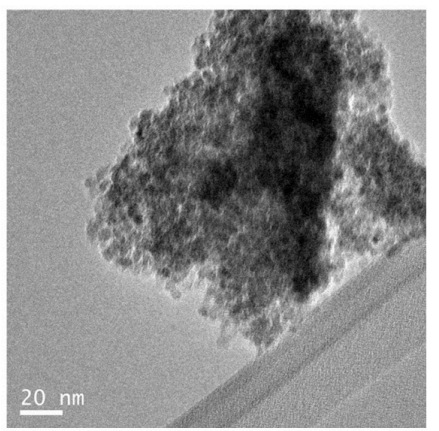

d)

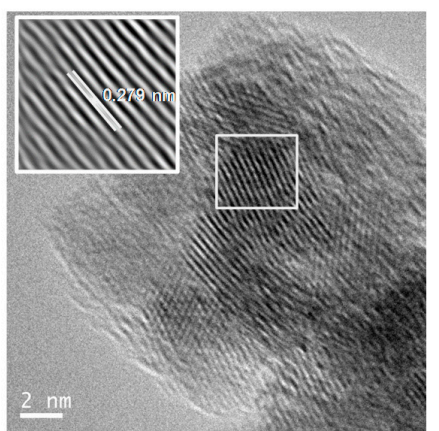

Figure 4. Characterization of $\mathrm{FeCO}_{3} \mathrm{NRs@CALB-Mentha.} \mathrm{(a)} \mathrm{XRD.} \mathrm{(b)} \mathrm{TEM.} \mathrm{(c)} \mathrm{HRTEM.} \mathrm{(d)} \mathrm{HRTEM}$ (inset IFFT).

The $\mathrm{FeCO}_{3} \mathrm{NRs@CALB} \mathrm{bionanohybrid} \mathrm{was} \mathrm{stored} \mathrm{at} \mathrm{room} \mathrm{conditions} \mathrm{for} 30$ days to evaluate its stability. After that, XRD image showed that no significant changes were observed in the iron species (Figure 5). TEM images revealed a slight increase in the width and the length of the nanorods, increasing the latter from around $60 \mathrm{~nm}$ to $88 \mathrm{~nm}$ (Figure 5).

a)

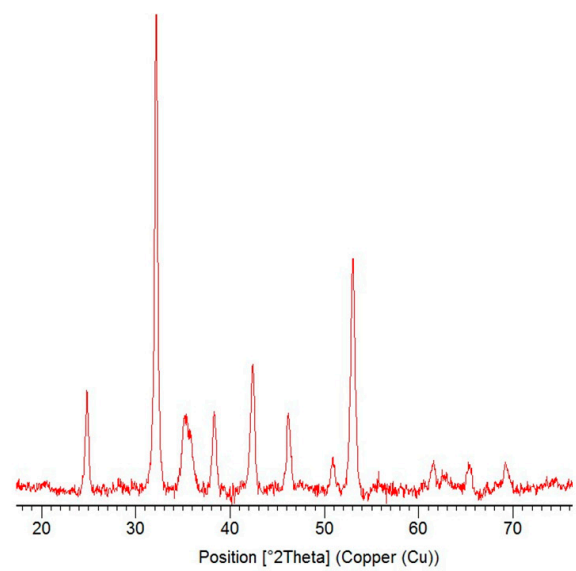

c)

\begin{tabular}{|c|c|c|}
\hline $\mathrm{FeCO}_{3} \mathrm{NRs@CALB}$ & Day 1 & Day 30 \\
\hline $\begin{array}{c}\text { Diameter of } \\
\text { nanorodsinm }\end{array}$ & $\mathbf{7 \pm 1}$ & $\mathbf{8 \pm 2}$ \\
\hline Length of nanorods/nm & $\mathbf{6 0 \pm 1 0}$ & $\mathbf{8 8 \pm 1 4}$ \\
\hline
\end{tabular}

b)
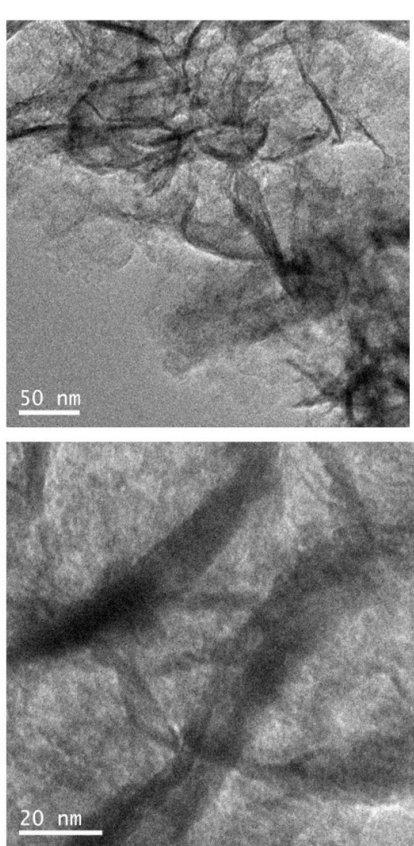

Figure 5. Characterization of $\mathrm{FeCO}_{3} \mathrm{NRs@CALB}$ after 30 days. (a) XRD pattern nanocomposite. (b) TEM images of the nanocomposite. (c) Comparison of nanorods size of the nanocomposite at day 1 and day 30 after synthesis. 


\subsection{Degradation of $p A P$ Catalyzed by $\mathrm{FeCO}_{3} \mathrm{NRs} @ \mathrm{CALB}$}

$\mathrm{FeCO}_{3} \mathrm{NRs@CALB} \mathrm{biohybrid} \mathrm{was} \mathrm{used} \mathrm{as} \mathrm{catalyst} \mathrm{in} \mathrm{the} \mathrm{degradation} \mathrm{of} \mathrm{pAP} \mathrm{(100} \mathrm{mg/L).} \mathrm{First,}$ substrate was solubilized in distilled water ( $\mathrm{pH}$ around 7 ) and nanocatalyst $(3 \mathrm{mg})$ were added to $2 \mathrm{~mL}$ of pAP solution. Under these conditions, containing $1 \%(v / v)$ of $\mathrm{H}_{2} \mathrm{O}_{2}$ at room temperature, more than $95 \%$ degradation of pAP was observed after $10 \mathrm{~min}$. Similar results were obtaining using $5 \mathrm{mM}$ phosphate buffer at 7 as solvent. To evaluate the effect of $\mathrm{pH}$ in the catalytic performance, the reaction was repeated using pAP previously dissolved in sodium acetate buffer $\mathrm{pH} 4$ (Figure 6). Iron nanocatalysts were faster at these conditions, and pAP was degraded in $2 \mathrm{~min}$ in the presence of $1 \%(v / v)$ of $\mathrm{H}_{2} \mathrm{O}_{2}$. Importantly, no traces of any compounds were detected by HPLC after $50 \mathrm{~min}$.

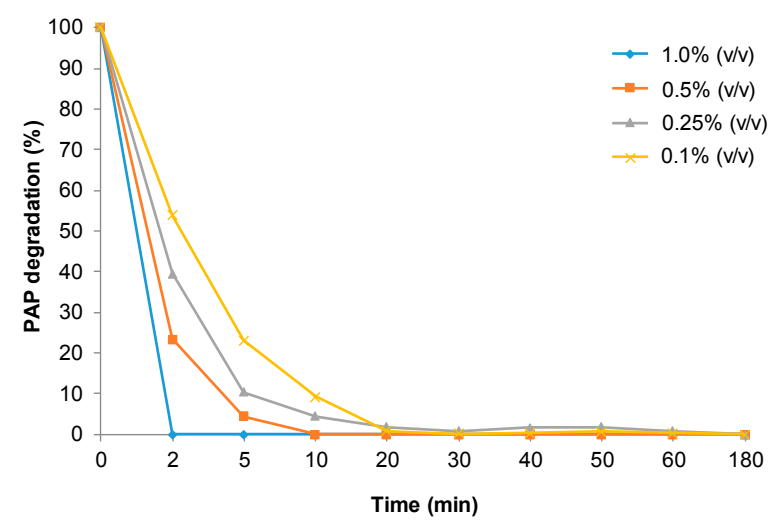

Figure 6. Profile of pAP degradation in acetate buffer at $\mathrm{pH} 4$ containing different amount of $\mathrm{H}_{2} \mathrm{O}_{2}$ catalyzed by $\mathrm{FeCO}_{3} \mathrm{NRs@CALB.}$

Considering the rate obtained at this $\mathrm{pH}$, the amount of $\mathrm{H}_{2} \mathrm{O}_{2}$ was evaluated. The reaction was slower in the presence of $0.5 \%(v / v) \mathrm{H}_{2} \mathrm{O}_{2}$ and full degradation was achieved after $10 \mathrm{~min}$. Using less amount of oxidant, the catalytic performance of $\mathrm{FeCO}_{3} \mathrm{NRs@CALB} \mathrm{was} \mathrm{reduced} \mathrm{and} \mathrm{pAP} \mathrm{degradation}$ was not complete before 30 min (Figure 6).

\subsection{Degradation of pAP Catalyzed by $\mathrm{FeCO}_{3} \mathrm{NP}_{\mathrm{s}} @ \mathrm{CALB}-\mathrm{Mentha}$}

The catalytic capacity of the new biohybrid $\mathrm{FeCO}_{3} \mathrm{NPs} @ \mathrm{CALB}-M e n t h a$ was also tested in the catalytic degradation of pAP $(100 \mathrm{mg} / \mathrm{L})$ using $1 \%(v / v) \mathrm{H}_{2} \mathrm{O}_{2}$. The reaction was very fast in distilled

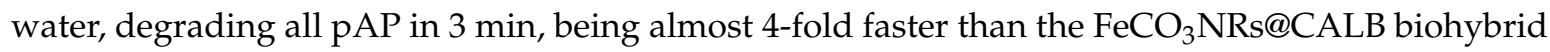
under these conditions (Figure 7a). The reaction was also performed using $0.2 \mathrm{~g}$ of catalyst per $\mathrm{L}$ of the reaction volume. At these conditions, pAP was completely degraded in $15 \mathrm{~min}$ (Figure $7 \mathrm{~b}$ ).

a)

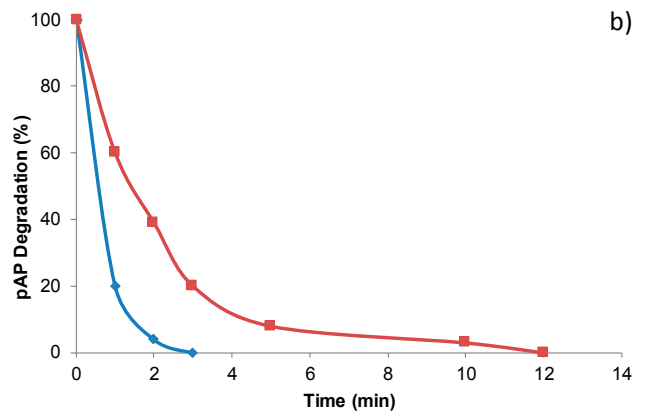

b)

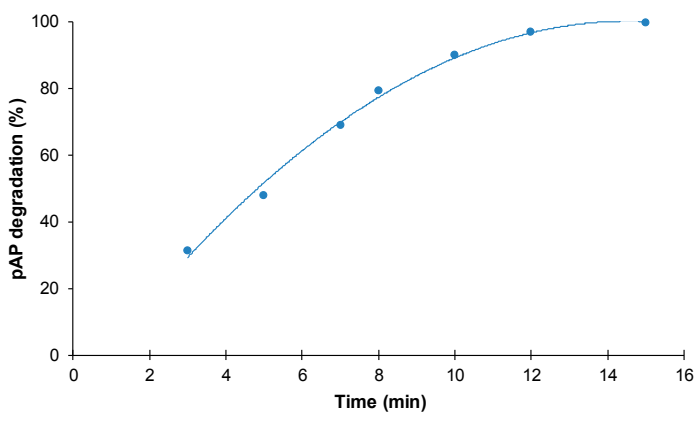

Figure 7. Profile of pAP degradation in water containing $1 \%(v / v)$ of $\mathrm{H}_{2} \mathrm{O}_{2}$ catalyzed by bionanohybrids. (a) Comparison between $\mathrm{FeCO}_{3} \mathrm{NRs@CALB}$ (red line) and $\mathrm{FeCO}_{3} \mathrm{NPs} @ \mathrm{CALB}-$ Mentha (blue line) at $2 \mathrm{~mL}$ reaction volume. (b) $\mathrm{FeCO}_{3} \mathrm{NPs} @ \mathrm{CALB}-$ Mentha at $10 \mathrm{~mL}$ reaction volume. The amount of catalyst was $3 \mathrm{mg}$ in all cases. 
Then, catalytic capacity of this biohybrid was tested under different $\mathrm{pHs}$ (Table 1). In this case, acidic conditions ( $\mathrm{pH} 4)$ were tested using acetate buffer $(10$ or $100 \mathrm{mM})$ or directly in acidic water $\mathrm{pH}$ adjusted using $\mathrm{HCl}$. Tap water was also used for the reaction, giving similar results to those obtained using distilled water (Table 1).

Table 1. pAP degradation at different conditions catalyzed by $\mathrm{FeCO}_{3} \mathrm{NRs@CALB-Mentha}{ }^{\text {a }}$.

\begin{tabular}{ccccc}
\hline Solvent & $(\mathbf{m M})$ & $\mathbf{p H}$ & Time (min) & pAP Degradation (\%) \\
\hline Acetate & 100 & 4 & 20 & 81 \\
Acetate & 10 & 4 & 20 & 76 \\
Adjusted Tap water & - & 4 & 17 & 66 \\
Phosphate & 0.5 & 6 & 16 & 99 \\
Phosphate & 0.5 & 7 & 15 & 99 \\
Tap water & - & 7.4 & 16 & 99 \\
Distilled $\mathrm{H}_{2} \mathrm{O}$ & - & 7 & 15 & 99
\end{tabular}

a Reaction conditions were: $3 \mathrm{mg}$ catalyst, $10 \mathrm{~mL}$ of pAP solution in distilled water $(100 \mathrm{mg} / \mathrm{L}), 1 \%(v / v)$ hydrogen peroxide, room temperature.

$\mathrm{FeCO}_{3} \mathrm{NPs} @ \mathrm{CALB}-$ Mentha showed less catalytic activity at lower $\mathrm{pH}$, and around 80\% degradation was obtained after $20 \mathrm{~min}$ at $\mathrm{pH} 4$ acetate buffer (Table 1, entries 1-2). The use of acidic water even resulted in worse conversion values (Table 1 , entry 3 ).

Considering the low effect of buffer presence on the biohybrid, $0.5 \mathrm{mM}$ phosphate buffer was used to adjust $\mathrm{pH}$ to 6 or 7 . Reaction was slightly faster at $\mathrm{pH} 7$ than $\mathrm{pH} 6$ with complete substrate degradation in $15 \mathrm{~min}$, similar results that those obtained using distilled or tab water (Table 1).

Therefore, optimal condition for the degradation of 100 ppm of pAP catalyzed by $\mathrm{FeCO}_{3} \mathrm{NPs} @ \mathrm{CALB}-M e n t h a$ was obtained using water as solvent, whereas for $\mathrm{FeCO}_{3} \mathrm{NRs}_{\mathrm{C}} \mathrm{CALB}$ was using acetate (Figure 6). In both cases, the mechanism of degradation was similar to the previous reported, where pAP was oxidized to hydroquinone (HQ) and p-benzoquinone and finally the benzene rings are opened and oxidized to other smaller compounds which finally most of them are degraded to $\mathrm{CO}_{2}$ and $\mathrm{H}_{2} \mathrm{O}[6,31]$. Considering the fast reaction, the effect of hydrogen peroxide concentration was again also tested with this catalyst (Figure 8).

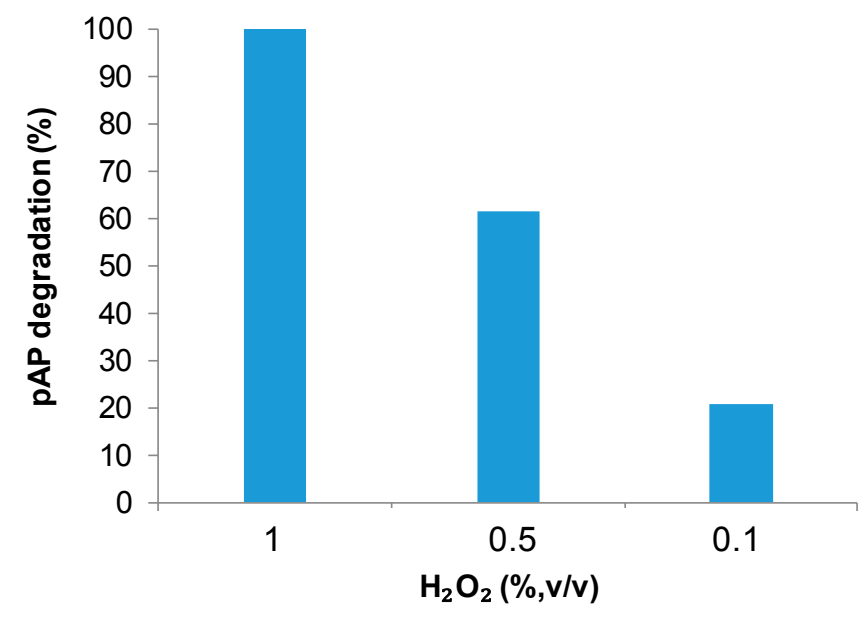

Figure 8. Effect of the amount of hydrogen peroxide in the PAP degradation catalyzed by hydrogen peroxide. Reaction conditions were $3 \mathrm{mg}$ catalyst, $10 \mathrm{~mL}$ of pAP solution in distilled water $(100 \mathrm{mg} / \mathrm{L})$, room temperature for $15 \mathrm{~min}$.

However, like the previous results with $\mathrm{FeCO}_{3} \mathrm{NRs@CALB}$, the catalytic capacity of the nanobiohybrid decreased $40 \%$ with the addition of $0.5 \%(v / v) \mathrm{H}_{2} \mathrm{O}_{2}$ and even more than $80 \%$ with adding $0.1 \%(v / v)$. 
Finally, to evaluate the possible industrial applicability of this catalyst, a recycling process was tested under optimal conditions: distilled water as solvent and 1\% (v/v) hydrogen peroxide (Figure 9). Catalyst was used for five cycles in the degradation process without loss of catalytic performance.

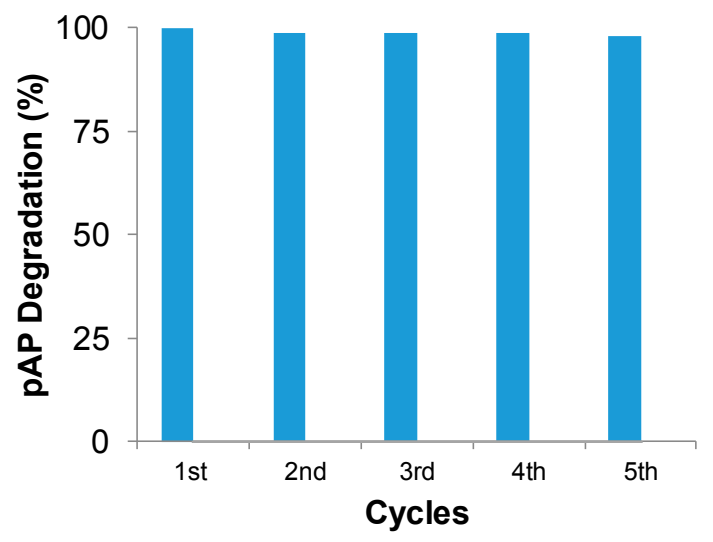

Figure 9. Reuse of $\mathrm{FeCO}_{3} \mathrm{NPs} @ \mathrm{CALB}-M e n t h a$ in the degradation of pAP. Reaction conditions were: $3 \mathrm{mg}$ catalyst, $2 \mathrm{~mL}$ of $\mathrm{pAP}$ solution in distilled water $(100 \mathrm{mg} / \mathrm{L})$, room temperature for $3 \mathrm{~min}$.

Thus, these new nanocatalysts constitute a very promising alternative for the degradation of organic pollutants, especially pAP, where in many cases these results improve the efficiency in terms of time of degradation and amount of sample achieved using other catalysts described in the literature for this reaction $[7,8]$.

\section{Materials and Methods}

Candida antarctica lipase B (CAL-B) solution was from Novozymes (Copenhagen, Denmark). Ammonium iron(II) sulfate hexahydrate $\left[\left(\mathrm{NH}_{4}\right)_{2} \mathrm{Fe}\left(\mathrm{SO}_{4}\right)_{2} \times 6 \mathrm{H}_{2} \mathrm{O}\right.$ (Mohr's salt)], hydrogen peroxide (33\%), p-aminophenol, sodium bicarbonate and sodium borohydride were purchased from Sigma-Aldrich (St. Louis, MO, USA). HPLC grade acetonitrile was purchased from Scharlab (Barcelona, Spain). Tap water came from the Canal de Isabel II (Madrid Region, Spain).

Inductively coupled plasma atomic emission spectrometry (ICP-AES) was performed on a OPTIMA 2100 DV instrument (PerkinElmer, Waltham, MA, USA). X-Ray diffraction (XRD) patterns were obtained using a Texture Analysis D8 Advance Diffractometer (Bruker, Billerica, MA, USA) with $\mathrm{Cu} \mathrm{K} \alpha$ radiation. X-ray photoelectron analysis (XPS) was carried out on SPECS GmbH (Berlin, Germany) spectrometer equipped with a Phoibos 150 9MCD energy analyzer. A non-monochromatic aluminum X-ray source with a power of $200 \mathrm{~W}$ and voltage of $12 \mathrm{kV}$ was used using as reference standard the C1s adventitial carbon $284.8 \mathrm{eV}$. Transmission electron microscopy (TEM) and high resolution TEM microscopy (HRTEM) images were obtained on a 2100F microscope (JEOL, Tokyo, Japan) equipped with an EDX detector INCA x-sight (Oxford Instruments, Abingdon, UK). Interplanar spacing in the nanostructures was calculated by using the inversed Fourier transform with the GATAN digital micrograph program (Corporate Headquarters, Pleasanton, CA, USA). Scanning electron microscopy (SEM) imaging was performed on a TM-1000 microscope (Hitachi, Tokyo, Japan). To recover the biohybrids, a Biocen 22 R (Orto-Alresa, Ajalvir, Spain) refrigerated centrifuge was used. Spectrophotometric analyses were run on a V-730 spectrophotometer (JASCO, Tokyo, Japan). A spectrum P100 HPLC system (Thermo Scientifics, Waltham, MA, USA) was used. Analyses were run at $25^{\circ} \mathrm{C}$ using an L-7300 column oven (Hitachi, Tokyo, Japan) and a UV6000LP detector (Thermo Scientifics, Waltham, MA, USA). 


\subsection{Synthesis of Nanostructured FeCO ${ }_{3} \mathrm{NRs@CALB} \mathrm{Hybrid}$}

Commercial Candida antarctica lipase B solution $(3.6 \mathrm{~mL}$, containing $4 \mathrm{mg}$ lipase $/ \mathrm{mL})$ was added to $60 \mathrm{~mL}$ sodium bicarbonate buffer $0.1 \mathrm{M} \mathrm{pH} 10$ in a $100 \mathrm{~mL}$ glass bottle containing a small magnetic bar stirrer $(12 \times 4.5 \mathrm{~mm})$. The solution was stirred in a magnetic agitator at $380 \mathrm{rpm}$ (this is important to avoid iron oxidation) for $2 \mathrm{~min}$. Then $\mathrm{Fe}\left(\mathrm{NH}_{4}\right)_{2}\left(\mathrm{SO}_{4}\right)_{2} \cdot 6 \mathrm{H}_{2} \mathrm{O}(600 \mathrm{mg}, 10 \mathrm{mg} / \mathrm{mL})$ was added to the protein solution, while maintaining the stirring. This was continued for $16 \mathrm{~h}$ at room temperature. After the first $30 \mathrm{~min}$ of incubation, the solution turned cloudy (greenish-gray) and the $\mathrm{pH}$ decreased from 10 to $7-8$. After $16 \mathrm{~h}$ of incubation, the solution turned very dark green. Then, the mixture was centrifuged at $8000 \mathrm{rpm}$ for $5 \mathrm{~min}$, adding $11 \mathrm{~mL}$ per each $15 \mathrm{~mL}$ Falcon-type tube. The generated pellet was resuspended in $15 \mathrm{~mL}$ of distilled water and centrifuged again at $8000 \mathrm{rpm}$ for $5 \mathrm{~min}$ and the supernatant removed. This process was repeated once more. Finally, the supernatant was removed, and the pellet of each Falcon tube was resuspended in $2 \mathrm{~mL}$ of water, all solutions combined in a round-bottomed flask, frozen with liquid nitrogen and lyophilized for $16 \mathrm{~h}$. Characterization of the bionanohybrid was performed by XRD, XPS, SEM and TEM analysis. The bionanohybrid was again characterized after 1 month of preparation.

\subsection{Preparation of the Extracted Aqueous Solution of Mentha x Piperita}

Dry leaves of Mentha x piperita (10 g, purchased from SoriaNatural, Garray, Spain) were added to $100 \mathrm{~mL}$ of previously heated bi-distilled water (at $100{ }^{\circ} \mathrm{C}$ ). This mixture was boiled for $10 \mathrm{~min}$. Then, the brown dark solution obtained was recovered by centrifugation $(10,000 \mathrm{rpm})$ and filtration. To separate plant material from the aqueous solution, the mixture was transferred to centrifuge tubes and centrifuged at $10,000 \mathrm{rpm}$ for $10 \mathrm{~min}$ at $12{ }^{\circ} \mathrm{C}$. Supernatant was collected and filtered using filter paper (Prat Dumas, Couze-et Saint Front, France) to completely remove any remaining solid. Liquid plant extract was used immediately after preparation.

\subsection{Synthesis of Nanostructured FeCO ${ }_{3} N P s @ C A L B-M e n t h a$ Biohybrid.}

Commercial Candida antarctica lipase B solution $(3 \mathrm{~mL})$ was added to sodium bicarbonate buffer $(60 \mathrm{~mL}, 0.1 \mathrm{M}, \mathrm{pH} 10)$ in a $100 \mathrm{~mL}$ glass bottle containing a small magnetic bar stirrer $(12 \times 4.5 \mathrm{~mm})$. The solution was stirred on a magnetic agitator at $380 \mathrm{rpm}$ for $2 \mathrm{~min}$. Then Fe( $\left(\mathrm{NH}_{4}\right)_{2}\left(\mathrm{SO}_{4}\right)_{2} \cdot 6 \mathrm{H}_{2} \mathrm{O}$ $(600 \mathrm{mg}, 10 \mathrm{mg} / \mathrm{mL}$ ) were added to the protein solution, while maintaining the stirring. After 16 $\mathrm{h}$ of incubation at room temperature, the solution turned very dark green. Then, the mixture was centrifuged at $8000 \mathrm{rpm}$ for $5 \mathrm{~min}$, and the supernatant was discarded. The solid was dissolved in $60 \mathrm{~mL}$ of an aqueous extract of Mentha x piperita for $30 \mathrm{~min}$. The solution turned black immediately after the addition of the Mentha extract. Then the mixture was centrifuged at $8000 \mathrm{rpm}$ for $5 \mathrm{~min}$. The supernatant was discarded and pellet was resuspended in $15 \mathrm{~mL}$ of water. It was centrifuged again at $8000 \mathrm{rpm}$ for $5 \mathrm{~min}$ and the supernatant removed. The process was repeated once more. Finally, the recovered pellet of each Falcon was resuspended in $2 \mathrm{~mL}$ of water. Solutions were frozen with liquid nitrogen and lyophilized for $16 \mathrm{~h}$. Characterization of the novel iron nanostructured hybrid was performed by XRD and TEM analysis.

\subsection{Catalytic Degradation of $p$-Aminophenol by Iron Nanostructured Catalyst}

pAP ( $2 \mathrm{mg}$ ) was dissolved in solutions $(18.88 \mathrm{~mL})$ of distilled water, acidic water $\mathrm{pH} 4$, acetate buffer $(\mathrm{pH} 4)$ or phosphate buffer $(\mathrm{pH} 6.7)$ and different amount of hydrogen peroxide $(\%, v / v)$ (from 0.02 to $0.22 \mathrm{~mL}$ ) were added. To initialize the reaction, 2 or $10 \mathrm{~mL}$ of this solution were added to a glass bottle containing $3 \mathrm{mg}$ of bionanohybrid and stirred gently at room temperature on an orbital shaker (320 rpm). In the case of using $\mathrm{FeCO}_{3} \mathrm{NPs} @$ CALB-Mentha, the reaction was performed using $3 \mathrm{mg}$ of catalyst in $10 \mathrm{~mL}$ of pAP $1 \mathrm{mM}$ solution. Experiments were performed in triplicate.

At different times samples $(80 \mu \mathrm{L})$ were taken and the reaction was followed by HPLC. Samples were first centrifuged at $8000 \mathrm{rpm}$ for $5 \mathrm{~min}$ and then $50 \mu \mathrm{L}$ were diluted 40 times in bi-distilled water 
before injection. HPLC column was C8 Kromasil $150 \times 4.6 \mathrm{~mm}$ AV-2059. HPLC conditions were: an isocratic mixture of $30 \%$ acetonitrile and $70 \%$ bi-distilled water, UV detection at $270 \mathrm{~nm}$ using a Diode array detector, and a flow rate of $0.6 \mathrm{~mL} / \mathrm{min}$. Under these conditions, retention times of pAP and $\mathrm{H}_{2} \mathrm{O}_{2}$ were $4.03 \mathrm{~min}$, and $2.6 \mathrm{~min}$ respectively. The possible adsorption of substrate to the catalyst was first tested and without the presence of hydrogen peroxide no reaction was observed and the full area of the substrate was unaltered in the HPLC analysis.

\subsection{Reuse of $\mathrm{FeCO}_{3} \mathrm{NPs} @ \mathrm{CALB}-\mathrm{Mentha}$ Hybrid}

$\mathrm{FeCO}_{3} \mathrm{NPs} @ \mathrm{CALB}-M e n t h a$ catalyst was reused five cycles in the degradation of 100 ppm of pAP at optimal conditions: pAP in distilled water, $1 \%(v / v)$ hydrogen peroxide using $3 \mathrm{mg}$ of catalyst in $2 \mathrm{~mL}$ of solution. A syringe with a filter was used to perform the reaction, removing the solution when finished while preventing leakage of the catalyst. An adjustment (around 10\%) due to the negligible loss of catalyst through the filter was applied. No leaching of iron content of the catalyst was determined, even after the fifth cycle.

\section{Conclusions}

Herein, we have described a very simple and efficient strategy to synthesize iron nanostructured catalysts. They were successfully applied in the ultra-fast full degradation of pAP in aqueous media. The biohybrid $\mathrm{FeCO}_{3} \mathrm{NRs} @ \mathrm{CALB}$, containing iron nanorods, worked better at pH 4 whereas the $\mathrm{FeCO}_{3} \mathrm{NPs} @ \mathrm{CALB}-\mathrm{Mentha}$, containing iron nanoparticles, was better at pH 7. In both cases, 100 ppm of pAP was degraded around $2-3 \mathrm{~min}$ at $1 \mathrm{~g}$ cat $/ \mathrm{L}$ or $15 \mathrm{~min}$ at $0.2 \mathrm{~g}$ cat/L. The nanobiohybrids were quite stable and could be recycled at least 5 times without any decrease in their catalytic capacity.

Author Contributions: R.B., D.L.-T. and C.P.-R. performed the experiments; J.M.P. designed and supervised the study and experiments, and J.M.P., D.L.-T. and C.P.-R. wrote the manuscript.

Funding: This research was supported by GRO PROGRAM 2017 and SAMSUNG L.S. The authors thank the support by the Spanish National Research Council (CSIC) (CSIC-PIE 201880E011). We also thank to the Ministry of Education, Youth and Sports of the Community of Madrid and the European Social Fund for a contract to C.P.-R. (PEJD-2017PRE/SAL-3762) in the program of Youth Employment and the Youth Employment Initiative (YEI) 2017.

Acknowledgments: We thank Ramiro Martínez from Novozymes.

Conflicts of Interest: The authors declare no conflicts of interest.

\section{References}

1. Afzal Khan, S.; Hamayun, M.; Ahmed, S. Degradation of 4-aminophenol by newly isolated Pseudomonas sp. strain ST-4. Enzyme Microb. Technol. 2006, 38, 10-13. [CrossRef]

2. Xu, H.; Duan, C.-F.; Zhang, Z.-F.; Chen, J.-Y.; Lai, C.-Z.; Lian, M.; Liu, L.-J.; Cui, H. Flow injection determination of $p$-aminophenol at trace level using inhibited luminol-dimethylsulfoxide-NaOH-EDTA chemiluminescence. Water Res. 2005, 39, 396-402. [CrossRef] [PubMed]

3. Filik, H.; Hayvalı, M.; Kılıç, E.; Apak, R.; Aksu, D.; Yanaz, Z.; Çengel, T. Development of an optical fibre reflectance sensor for $p$-aminophenol detection based on immobilised bis-8-hydroxyquinoline. Talanta 2008, 77, 103-109. [CrossRef] [PubMed]

4. Harmon, R.C.; Kiningham, K.K.; Valentovic, M.A. Pyruvate reduces 4-aminophenol in vitro toxicity. Toxicol. Appl. Pharmacol. 2006, 213, 179-186. [CrossRef] [PubMed]

5. Lin, M.; Hu, X.; Ma, Z.; Chen, L. Functionalized polypyrrole nanotube arrays as electrochemical biosensor for the determination of copper ions. Anal. Chim. Acta 2012, 746, 63-69. [CrossRef] [PubMed]

6. Ghosh, P.; Ghime, D.; Lunia, D. Degradation of $p$-aminophenol by Fenton's process. Influence of operational parameters. Environ. Prot. Eng. 2017, 43. [CrossRef]

7. Nezamzadeh-Ejhieh, A.; Amiri, M. CuO supported Clinoptilolite towards solar photocatalytic degradation of $p$-aminophenol. Powder Technol. 2013, 235, 279-288. [CrossRef] 
8. Nezamzadeh-Ejhieh, A.; Shirvani, K. CdS Loaded an Iranian Clinoptilolite as a Heterogeneous Catalyst in Photodegradation of $p$-Aminophenol. J. Chem. 2013, 2013, 541736. [CrossRef]

9. Shylesh, S.; Schünemann, V.; Thiel, W.R. Magnetically Separable Nanocatalysts: Bridges between Homogeneous and Heterogeneous Catalysis. Angew. Chem. Int. Ed. 2010, 49, 3428-3459. [CrossRef] [PubMed]

10. Chng, L.L.; Erathodiyil, N.; Ying, J.Y. Nanostructured Catalysts for Organic Transformations. Acc. Chem. Res. 2013, 46, 1825-1837. [CrossRef] [PubMed]

11. Cheng, M.; Zeng, G.; Huang, D.; Lai, C.; Liu, Y.; Xu, P.; Zhang, C.; Wan, J.; Hu, L.; Xiong, W.; et al. Salicylic acid-methanol modified steel converter slag as heterogeneous Fenton-like catalyst for enhanced degradation of alachlor. Chem. Eng. J. 2017, 327, 686-693. [CrossRef]

12. Li, B.; Lai, C.; Zeng, G.; Qin, L.; Yi, H.; Huang, D.; Zhou, C.; Liu, X.; Cheng, M.; Xu, P.; et al. Facile Hydrothermal Synthesis of Z-Scheme $\mathrm{Bi}_{2} \mathrm{Fe}_{4} \mathrm{O}_{9} / \mathrm{Bi}_{2} \mathrm{WO}_{6}$ Heterojunction Photocatalyst with Enhanced Visible Light Photocatalytic Activity. ACS Appl. Mater. Interfaces 2018, 10, 18824-18836. [CrossRef] [PubMed]

13. Medicines Agency. Guideline on the Specification Limits for Residues of Metal Catalysts or Metal Reagents; EMEA/CHMP/SWP/4446/2000; Medicines Agency: London, UK, 2008.

14. Sayed, F.N.; Polshettiwar, V. Facile and Sustainable Synthesis of Shaped Iron Oxide Nanoparticles: Effect of Iron Precursor Salts on the Shapes of Iron Oxides. Sci. Rep. 2015, 5, 9733. [CrossRef] [PubMed]

15. Lopez-Tejedor, D.; Benavente, R.; Palomo, J.M. Iron nanostructured catalysts: Design and applications. Catal. Sci. Technol. 2018, 8. [CrossRef]

16. Preparing and Using Metal Nanoparticles. Patent WO 2014132106 A1, 4 September 2014.

17. Reddy, L.H.; Arias, J.L.; Nicolas, J.; Couvreur, P. Magnetic Nanoparticles: Design and Characterization, Toxicity and Biocompatibility, Pharmaceutical and Biomedical Applications. Chem. Rev. 2012, 112, 5818-5878. [CrossRef] [PubMed]

18. Benavente, R.; Lopez-Tejedor, D.; Palomo, J.M. Synthesis of a superparamagnetic ultrathin $\mathrm{FeCO}_{3}$ nanorods-enzyme bionanohybrid as a novel heterogeneous catalyst. Chem. Commun. 2018, 54, 6256-6259. [CrossRef] [PubMed]

19. Shin, S.; Kim, S.-W.; Jang, J.-H.; Kim, J.-B. A simple maskless process for the fabrication of vertically aligned high density hematite and graphene/magnetite nanowires. J. Mater. Chem. C 2017, 5, 1313-1320. [CrossRef]

20. Wang, F.; Wu, X.; Shen, C.; Wen, Z. Facile synthesis of $\mathrm{Fe} @ \mathrm{Fe}_{2} \mathrm{O}_{3}$ core-shell nanowires as $\mathrm{O}_{2}$ electrode for high-energy Li-O $\mathrm{O}_{2}$ batteries. J. Solid State Electrochem. 2016, 20, 1831-1836. [CrossRef]

21. Krajewski, M.; Lin, W.S.; Lin, H.M.; Brzozka, K.; Lewinska, S.; Nedelko, N.; Slawska-Waniewska, A.; Borysiuk, J.; Wasik, D. Structural and magnetic properties of iron nanowires and iron nanoparticles fabricated through a reduction reaction. Beilstein J. Nanotechnol. 2015, 6, 1652-1660. [CrossRef] [PubMed]

22. Lupan, O.; Postica, V.; Wolff, N.; Polonskyi, O.; Duppel, V.; Kaidas, V.; Lazari, E.; Ababii, N.; Faupel, F.; Kienle, L.; et al. Localized Synthesis of Iron Oxide Nanowires and Fabrication of High Performance Nanosensors Based on a Single $\mathrm{Fe}_{2} \mathrm{O}_{3}$ Nanowire. Small 2017, 13, 1602868. [CrossRef] [PubMed]

23. Patil, M.P.; Kim, G.-D. Eco-friendly approach for nanoparticles synthesis and mechanism behind antibacterial activity of silver and anticancer activity of gold nanoparticles. Appl. Microbiol. Biotechnol. 2017, 101, 79-92. [CrossRef] [PubMed]

24. Qin, L.; Zeng, G.; Lai, C.; Huang, D.; Xu, P.; Zhang, C.; Cheng, M.; Liu, X.; Liu, S.; Li, B.; et al. "Gold rush” in modern science: Fabrication strategies and typical advanced applications of gold nanoparticles in sensing. Coord. Chem. Rev. 2018, 359, 1-31. [CrossRef]

25. Singh, G.; Kumar, P.A.; Lundgren, C.; van Helvoort, A.T.J.; Mathieu, R.; Wahlström, E.; Glomm, W.R. Tunability in Crystallinity and Magnetic Properties of Core-Shell Fe Nanoparticles. Part. Part. Syst. Charact. 2014, 31, 1054-1059. [CrossRef]

26. Polshettiwar, V.; Asefa, T. Introduction to Nanocatalysis. In Nanocatalysis Synthesis and Applications; John Wiley \& Sons, Inc.: Hoboken, NJ, USA, 2013; pp. 1-9, ISBN 9781118609811.

27. Bradford, M.M. A rapid and sensitive method for the quantitation of microgram quantities of protein utilizing the principle of protein-dye binding. Anal. Biochem. 1976, 72, 248-254. [CrossRef]

28. Wu, X.; Xu, P.; Duan, Y.; Hu, C.; Li, G. Surface magnetization of siderite mineral. Int. J. Min. Sci. Technol. 2012, 22, 825-830. [CrossRef]

29. Lafuente, B.; Downs, R.T.; Yang, M.H.; Stone, N. The power of databases: The RRUFF project. In Highlights in Mineralogical Crystallography; Armbruster, T., Danisi, R.M., Eds.; W. De Gruyter: Berlin, Germany, 2015; pp. 1-30. 
30. Qu, X.-F.; Yao, Q.-Z.; Zhou, G.-T. Synthesis of siderite microspheres and their transformation to magnetite microspheres. Eur. J. Mineral. 2011, 23, 759-770. [CrossRef]

31. Moctezuma, E.; Leyva, E.; Aguilar, C.A.; Luna, R.A.; Montalvo, C. Photocatalytic degradation of paracetamol: Intermediates and total reaction mechanism. J. Hazard. Mater. 2012, 243, 130-138. [CrossRef] [PubMed]

Sample Availability: Samples of the compounds are not available from the authors.

(C) 2018 by the authors. Licensee MDPI, Basel, Switzerland. This article is an open access article distributed under the terms and conditions of the Creative Commons Attribution (CC BY) license (http:/ / creativecommons.org/licenses/by/4.0/). 